\title{
Effects of pectolytic enzyme treatment and microfiltration on antioxidant components of elderberry juice
}

$$
\text { D. Furulyás }{ }^{1,2}
$$

e-mail: Furulyas.Diana@phd.uni-szie.hu

$$
\text { M. Stéger-Máté1 }
$$

e-mail:
F. Nyéki ${ }^{3}$

e-mail: Flora.Nyeki@hallgato.uni-szie.hu

$$
\begin{aligned}
& \text { É. Stefanovits-Bányai }{ }^{2} \\
& \text { e-mail: Banyai.Eva@etk.szie.hu }
\end{aligned}
$$

Stegerne.Mate.Monika@etk.szie.hu

Sz. Bánvölgyi ${ }^{3}$

e-mail: Banvolgyi.Szilvia@etk.szie.hu

${ }^{1}$ Szent István University, Faculty of Food Science,

Department of Food Preservation,

H-1118 Budapest, Villányi St 29-43., Hungary

${ }^{2}$ Szent István University, Faculty of Food Science,

Department of Applied Chemistry,

H-1118 Budapest, Villányi St 29-43., Hungary

${ }^{3}$ Szent István University, Faculty of Food Science,

Department of Food Engineering,

H-1118 Budapest, Villányi St 29-43., Hungary

Keywords and phrases: sambucus nigra, elderberry, antioxidant, enzyme treatment, microfiltration 
three different enzymes were added to pulps in order to evaluate the effect of different pectolytic enzyme treatments on the valuable components of elderberry juice. Control sample was prepared without enzyme. After treatment, squeezing, and clarification steps, microfiltration was carried out with ceramic membrane. The effect of this technology on the antioxidant capacity, total polyphenol content, and total anthocyanin content of the clarified elderberry juices has been evaluated in permeate and retentate samples, and membrane retention was calculated. Significantly lower antioxidant capacity was detected in the case of control sample than that obtained using enzyme-treated juices. Retention of antioxidant content on the microfiltration membrane was greatly reduced by using the enzymes. Higher valuable component yield was obtained using Fructozym $P$ enzyme compared with Pectinex BE XXL used in industry.

Elderberry (Sambucus nigra L.) is a genus of flowering plants (Angiospermatophyta), order of Dipsacales from Adoxaceae family (Borhidi, 1995; Atkinson \& Atkinson, 2002).

In contrast to the well-founded commercial products, the Sambucus nigra species gets unreasonably low attention as a herb. This fruit is a rich source of organic acids (malic acid, acetic acid, etc.), vitamins (A, C), microelements, amino acids, sugars, and also essential oils (Bernáth, 2000; Stégerné, 2010). Sidor and Gramza-Michatowska (2014) established that elderberry contains several high bioavailable antioxidant components: mainly polyphenols, anthocyanins, flavonols, phenol acids, and anthocyanidins.

Elderberry is consumed only in processed form. Therefore, food producers aim to preserve the biologically valuable molecules during food processing. Next to the beneficial compounds of berries, their natural colorant content accounts for the wide consumption of elderberry. Semi-finished elderberry products are produced in two ways: fruit concentrate and pulp to make common beverages, juices, syrups, jelly, and jam from them. During processing, a filtration technology is applied to clarify the juice, but this step may decrease the stability of valuable components (Stégerné, 2010).

One step of technological line of juice production is to break down the pectin molecules with pectolytic enzymes in order to release the beneficial molecules; so, the pressing technology becomes easier and more effective by enzyme treatment. Pectin, a heteropolysaccharide, is contained in the cell walls of all higher plants. In food industry, the main aim of using pectolytic enzymes is to stabilize quality and simplify technological processing (Barta \& Körmendy, 2007). 
D. Furulyás et al.

Our aim was to investigate the influence of pectolytic enzyme (Pectinex BE $X X L$, Trenolin Rot, and Fructozym $P$ ) on the phenolic, anthocyanin content, and antioxidant activities of elderberry (Sambucus nigra L.) pulps during juice processing.

\section{Materials and methods}

\subsection{Pre-treatment and elderberry juice production}

The berries of elderberry (Sambucus nigra L.) cultivars "Haschberg" were collected from Nagyvenyim horticultural plant in Hungary. The elderberry juice was prepared by enzyme treatment, pressing, and via microfiltration (MF) steps. The preparations of elderberry juice were performed according to the industrial practice in a pilot plant of Szent István University.

After washing and crushing steps, the pulp was heated at $80^{\circ} \mathrm{C}$ in order to inactivate the enzymes of the fruit. The next step was the enzyme treatment; so, the pulp was cooled down to the optimum degree of enzymes $\left(35^{\circ} \mathrm{C}\right)$. The effect of enzymes was studied during the experiments. Before pressing, the berries were treated with three different pectolytic enzymes (Pectinex BE $X X L$, which is used in industry, Trenolin Rot, and Fructozym $P$ ) and one sample was prepared without any enzyme. The enzymes were added to the crushed fruit and left to stand for 1 hour. The amount of enzyme depends on the applied enzyme and according to the industrial practice (Table 1). After the first treatment, the pulps were squeezed by manual pressing, followed by a second enzyme treatment with half the amount of the previously applied enzymes for 30 minutes to improve the efficiency of the pressing operation to facilitate microfiltration.

Table 1: Parameters of enzyme treatment

\begin{tabular}{lccl}
\hline \multicolumn{1}{c}{ Enzyme } & $\begin{array}{c}1^{\text {st }} \text { Enzyme } \\
\text { treatment }(\mathrm{ml} / \mathrm{kg})\end{array}$ & $\begin{array}{c}2^{\text {nd }} \text { Enzyme } \\
\text { treatment }(\mathrm{ml} / \mathrm{kg})\end{array}$ & Distributed by \\
\hline Pectinex BE XXL & 0.2 & 0.1 & Kerttrade Ltd. \\
Fructozym P & 0.06 & 0.03 & Kerttrade Ltd. \\
Trenolin Rot & 0.02 & 0.01 & Kerttrade Ltd. \\
\hline
\end{tabular}

After the enzyme treatments, the clarification experiments were carried out with Klar Sol Super $(0.35 \mathrm{mg} / \mathrm{l})$, the samples were left to stand for 20 minutes and then with ErbiGel $(0.1 \mathrm{mg} / \mathrm{l})$ for 10 minutes. 
The last step of juice preparation was filtration. Clarification experiments were carried out in the laboratorial microfiltration (MF) unit, whose scheme is shown in Fig. 1.

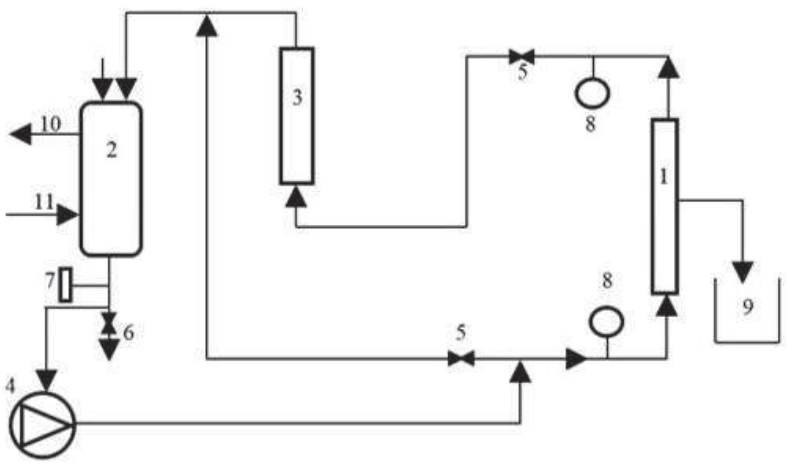

1 - membrane
2 - tank
3 - rotameter
4 - pump
5 - valve
6 - retentate
7 - thermometer
8 - manometer
9 - permeate
10 - cooling water input
11 - cooling water output

Figure 1: Scheme of the microfiltration unit

The filtration of enzyme-treated juice was applied to ceramic tube membrane (Pall Schumasiv) with an average pore size of $0.8 \mu \mathrm{m}$ and a permeable area of $0.005 \mathrm{~m}^{2}$. Inside the tube membrane, a static mixer was used to enhance the permeate flux.

The enzyme-treated juice was recirculated by a pump to the membrane surface, where a cross-flow system provided the reduced amount of fouling layer. The retentate (6. point) was recirculated to the feed tank, while the permeate (9. point) was collected in the beaker. Under the microfiltration process, the flow rate was constant at $150 \mathrm{l} / \mathrm{h}$, the applied transmembrane pressure was 3.5 bar, and the temperature was $30^{\circ} \mathrm{C}$.

\subsection{Antioxidant measurements}

Antioxidant capacity was determined by the FRAP (ferric reducing antioxidant power) assay (Benzie \& Strain, 1996). Ferric to ferrous ion reduction at low $\mathrm{pH}$ causes a coloured complex to form, and the absorbance change was detected at $\lambda=593 \mathrm{~nm}$. The results are expressed in ascorbic acid equivalent per litre (mg AAE/l).

The total polyphenol content (TPC) was measured with Folin-Ciocalteu reagents at $\lambda=765 \mathrm{~nm}$, using spectrophotometer. The calibration curve was made from gallic acid, using the Singleton and Rossi (1965) method. The results were shown in mg gallic acid equivalent per litre (mg GAE/l). 
The total anthocyanin content of samples was determined by $\mathrm{pH}$ differential method (Lee et al., 2005) based on the anthocyanin structural transformation, which occurs with a change in $\mathrm{pH}$ (coloured at $\mathrm{pH} 1.0$ and colourless at $\mathrm{pH}$ 4.5). The change of colour was detected at $\lambda=520 \mathrm{~nm}$. The results were expressed in mg per litre $(\mathrm{mg} / \mathrm{l})$.

The value of antioxidant capacity (FRAP), total polyphenol content (TPC), and total anthocyanin content (TAC) were calculated to the same dry matter content (it was measured by ATAGO pal- $\alpha$ digital refractometer).

\subsection{Statistical analyses}

Statistical analysis was carried out with the help of Microsoft Excel 2013. ANOVA and Student t-test were used to determine the differences between the resistances of four enzyme-treated samples during microfiltration and also to decide whether enzymes caused significant changes in antioxidant content. The $\mathrm{P}$ value $<0.05$ was considered to be significant.

\section{Results and discussion}

\section{Permeate flux}

During the microfiltration process, the suspended solids were removed from the elderberry juice. The MF of elderberry pulps was performed until we obtained $200 \mathrm{ml}$ permeate. Time and dry matter content were measured for every $10 \mathrm{ml}$ of permeate. After collecting $200 \mathrm{ml}$ of permeate, we removed it from the tank. The retentate, permeate, and the samples before filtration were kept under refrigeration at $-18^{\circ} \mathrm{C}$ until subjected to analytical measurements. The permeate flux of different enzyme-treated samples was calculated with the next equation:

$$
J=\frac{V}{A \cdot t}
$$

$$
\begin{aligned}
& \mathrm{J} \text { - flux }\left[\mathrm{l} / \mathrm{m}^{2} \mathrm{~h}\right], \\
& \mathrm{V} \text { - volume }[\mathrm{l}], \\
& \mathrm{A} \text { - membrane surface }\left[\mathrm{m}^{2}\right], \\
& \mathrm{t} \text { - time }[\mathrm{h}] .
\end{aligned}
$$

The effect of enzyme treatments on permeate flux is shown in Figure 2. In all the cases, the typical behaviour of the microfiltration process curve was observed. After a sharp initial flux, it declined due to membrane polarization, 
and flux stabilization occurred. According to data, the enzymes influenced the clarification process as well as the permeate flux and the filtration time.

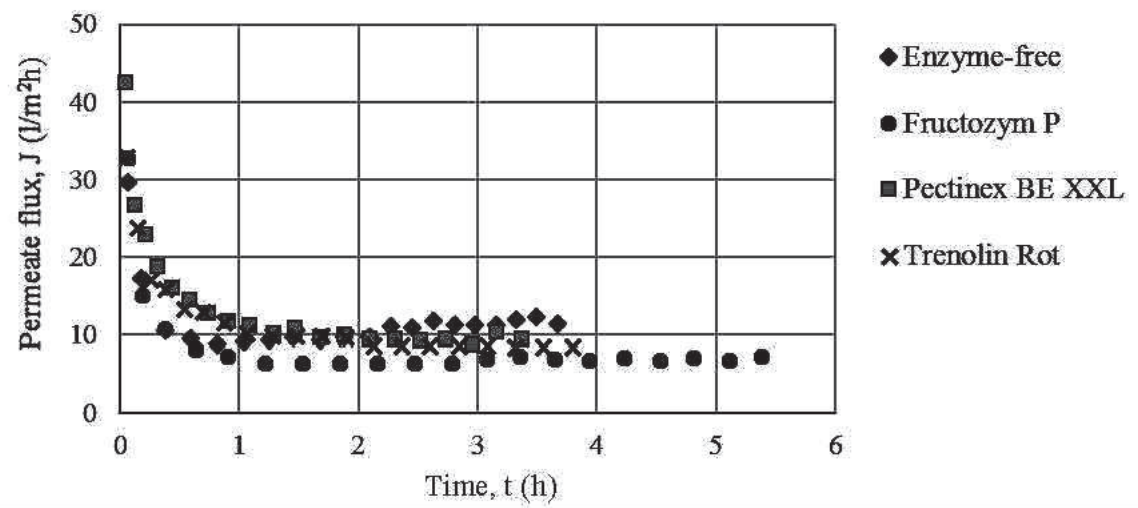

Figure 2: Effect of enzyme treatment on permeate flux during microfiltration

Comparing the values of initial flux, the best result $\left(42.6 \mathrm{l} / \mathrm{m}^{2} \mathrm{~h}\right)$ was obtained when using Pectinex BE XXL enzyme, which is used in food industry, whereas the lowest result was $29.6 \mathrm{l} / \mathrm{m}^{2} \mathrm{~h}$, obtained at the flux value of the enzyme-free pulp.

Considering the steady flux values, Pectinex BE XXL and Trenolin Rot enzymes were the same, around $10 \mathrm{l} / \mathrm{m}^{2} \mathrm{~h}$, while the enzyme-free pulp was 11 $\mathrm{l} / \mathrm{m}^{2} \mathrm{~h}$ and the steady flux of Fructozym $\mathrm{P}$ enzyme-treated juice was the lowest, around $6 \mathrm{l} / \mathrm{m}^{2} \mathrm{~h}$; therefore, using this enzyme treatment becomes uneconomical according to the other pre-treatment.

\section{Results of antioxidant measurements}

After the MF, the antioxidant quality of elderberry juices was measured by spectrophotometric methods. Differences were evaluated between antioxidant capacity, polyphenol, and anthocyanin content of pre-microfiltrated raw juice, permeate, and retentate samples in order to influence the enzyme treatments, and $\mathrm{MF}$ were investigated.

Figure 3 shows the antioxidant capacity of samples. The FRAP values were between $21.76 \mathrm{mg} \mathrm{AAE} / 1$ and $51.50 \mathrm{mg} \mathrm{AAE} / \mathrm{l}$. The clarified enzymefree elderberry pulps presented the lowest antioxidant content compared to enzyme-treated samples, while the most efficient antioxidant extraction was observed using Fructozym $P$ enzyme. Considering the raw-enzyme-treated juices, the lowest FRAP value was measured using Trenolin Rot enzyme, which 
is probably due to its lower pectolytic efficiency.

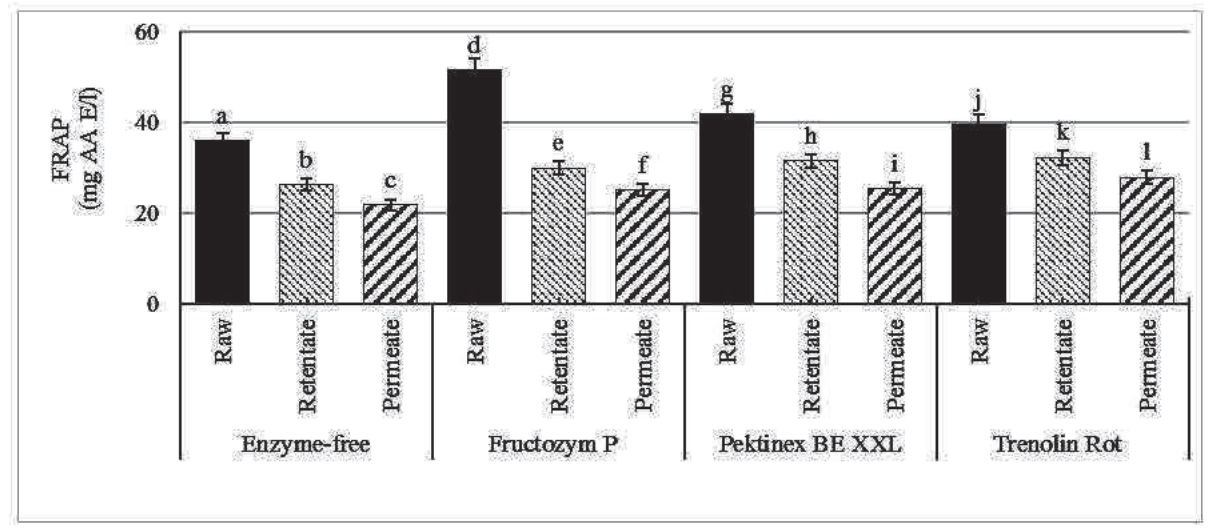

Figure 3: Average results of FRAP (data shown in mg AAE/l) a, b, c, etc. - the different letters significantly differ at $P<0.05$

The concentration of antioxidant capacity decreased during the microfiltration process; in the case of all enzyme-treated samples, the FRAP values in the permeate samples were higher than in the retentate.

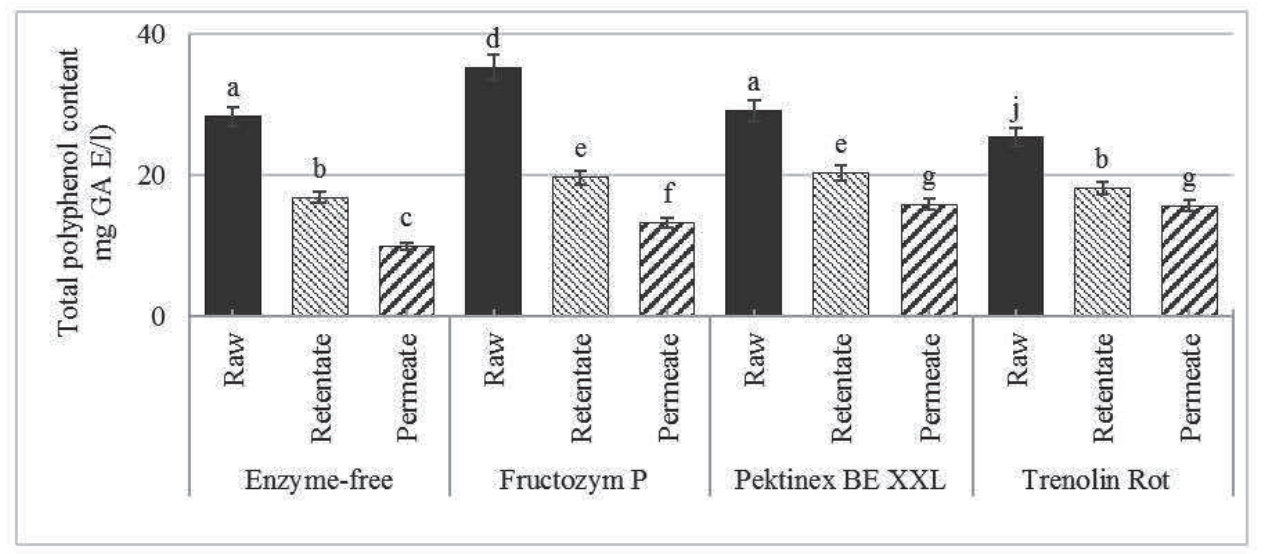

Figure 4: Average results of total polyphenol content (data shown in mg GAE/l)

a, b, c, etc. - the different letters significantly differ at $P<0.05$

The total polyphenol content of pulps is shown in gallic acid equivalent in Figure 4. Similarly, regarding the antioxidant capacity results and their 
changes: more polyphenol component was extracted by the enzyme treatment due to the pectin breakdown, except when using Trenolin Rot enzyme. The most efficient extraction was experienced with Fructozym $P$ enzyme-treated samples, where a significant difference $\left(p_{\text {value }}>0.05\right)$ was detected. The polyphenol content of the retentate was $50-70 \%$ of the raw juice, wherefore the TPC values of permeate were even lower.

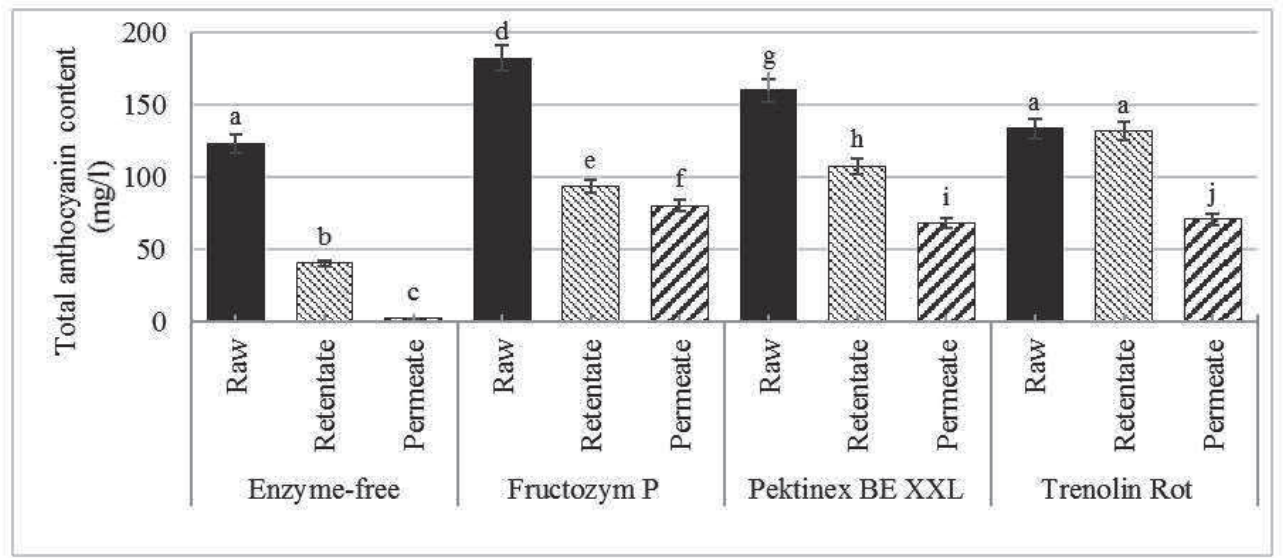

Figure 5: Average results of total anthocyanin content (data shown in $\mathrm{mg} / \mathrm{l}$ ) a, b, c, etc. - the different letters significantly differ at $P<0.05$

The total anthocyanin content of elderberry juice samples is shown in Figure 5. The anthocyanin content ranged from 1.74 to $182.43 \mathrm{mg} / \mathrm{l}$. The highest TAC of pre-microfiltrated raw pulps was again in the case of the Fructozym $P$ enzyme-treated sample, wherefore the lowest was found with the enzymefree pulp, which had $30 \%$ lower anthocyanin content than in the case of using Fructozym $P$ enzyme. Due to filtration, the highest reduction of TAC values was detected with the enzyme-free sample - the decrease was $98.6 \%$ in the case of the permeate and $67.4 \%$ in the case of the retentate.

Retention of membrane

The membrane of the microfiltration unit eliminates the suspended components to a varying degree. The rate of retention was calculated with the following equation:

$$
R=\left(1-\frac{C_{P}}{C_{R}}\right) * 100
$$

$\mathrm{R}$ is retention [\%], $C_{P}$ is permeate concentration, and $C_{R}$ is retentate concen- 
tration.

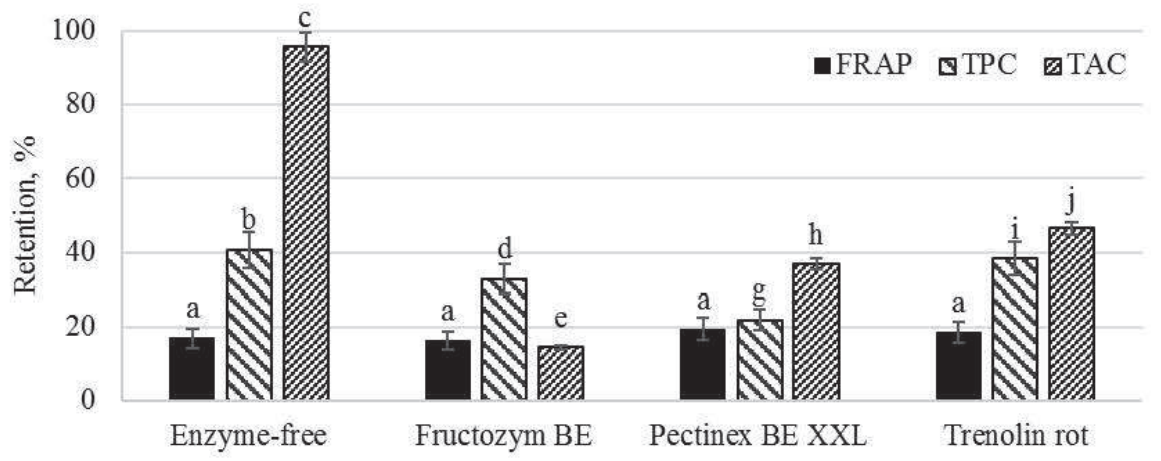

Figure 6: Retention rate of antioxidant components on the MF membrane FRAP: antioxidant capacity, TPC: total polyphenol content; TAC: total anthocyanin content a, b, c, etc. - the different letters significantly differ at $P<0.05$

Figure 6 shows the retention rate of antioxidant molecules. The membrane retained antioxidant components at the highest rate in the case of the sample prepared without enzyme treatment. Then enzyme treatment was carried out, and the retention of membrane significantly decreased. Considering the retention of antioxidant capacity and polyphenol content in the case of Trenolin Rot enzyme-treated samples, approximately the same retention rate was obtained as with enzyme-free samples. This retention rate was significantly higher than in the case of using Fructozym $P$ and Pectinex BE XXL enzymes.

\section{Conclusions}

The aim of this study was to evaluate the effects of pectolytic enzyme treatment (Pectinex BE XXL, Trenolin Rot, and Fructozym P) in the course of elderberry juice microfiltration and to observe how it affects the retention of the components responsible for antioxidant capacity.

The results of raw elderberry pulp measurements show that the enzyme treatments resulted in higher antioxidant components than the enzyme-free sample. Using Fructozym $P$ enzyme, pectin breakdown was reached more efficiently compared to Pectinex BE XXL, which is used in industry. The highest antioxidant capacity, polyphenol and anthocyanin content were determined in this pulp, although the time of MF also increased in this case. 
The lowest valuable components were measured using Trenolin Rot enzyme, where the results were statistically equal to the enzyme-free juice values.

Significant losses are believed to have occurred after the MF clarification process due to fouling of membrane pores, which can be decreased with pectolytic enzyme treatment. The most efficient filtration took place with the use of Fructozym $P$ and Pectinex BE XXL enzymes.

Research results of $Y u$ and Lencki (2004) are the same: according to the microfiltration of the enzyme-treated apple juice, more reduced antioxidant capacity, increased flux value, and lower resistance were detected than in the case of using enzyme-free pulp.

\section{Acknowledgements}

The authors acknowledge the financial help of OTKA 84290 and BoTÉSz.

\section{References}

[1] M. Atkinson, E. Atkinson, Sambucus nigra L. Journal of Ecology, (2002) 895-923.

[2] J. Barta, I., Körmendy, Növényi nyersanyagok feldolgozástechnológiai müveletei. Budapest, Mezőgazda Kiadó, (2007).

[3] I. F. F. Benzie, J. J. Strain, The ferric-reducing ability of plasma (FRAP) as a measure of "antioxidant power": the FRAP assay. Analytical Biochemistry, 239. (1996) 70-76.

[4] J. Bernáth, Gyógy- és aromanövények. Budapest, Mezőgazda Kiadó, (2000).

[5] A. Borhidi, A zárvatermők fejlődéstörténeti rendszertana. Budapest, Nemzeti Tankönyvkiadó, (1995).

[6] I. Gáspár, A. Román, Gy. Vatai, A. Koris, E. Marki, Effects of static mixing on the ultrafiltration of milk whey. Croatian Journal of Food Technology, Biotechnology and Nutrition, 5, 1-2. (2010) 5-9.

[7] J. Lee, R. Durst, R. Wrolstad, Determination of total monomeric anthocyanin pigment content of fruit juices, beverages, natural colorants and wines by the $\mathrm{pH}$ differential method: collaborative study. Journal of AOAC International, 88. (2005) 1269-1278. 
[8] A. Sidor, A. Gramza-Michalowska, Advanced research on the antioxidant and health benefit of elderberry (Sambucus nigra) in food - a review. Journal of Functional Foods, 18. (2015) 941-958.

[9] V. L. Singleton, J. A. Rossi, Colorimetry of total phenolics with phosphomolybdic-phosphotungstic acid reagents. American Journal of Enology and Viticulture, 16. (1965) 144-158.

[10] M. M. Stégerné, A fekete bodza feldolgozása. In: B. Sipos (ed.), A fekete bodza termesztése. Budapest: Mezőgazda Kiadó, (2010) 82-86.

[11] J. Yu, R. W. Lencki, Effect of enzyme treatments on the fouling behavior of apple juice during microfiltration. Journal of Food Engineering, 63. (2004) 413-423. 